\title{
The Attitudes of Science and Mathematics Teachers toward the Integration of Information and Communication Technology (ICT) in their Educational Practice: The Application of the Unified Theory of Acceptance and Use of Technology (UTAUT)
}

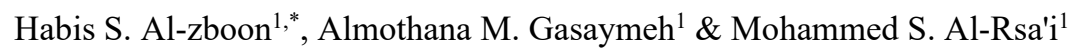

${ }^{1}$ Department of Curriculum and Instruction, College of Education, Al-Hussein Bin Talal University, Ma'an, Jordan

*Correspondence: Department of Curriculum and Instruction, College of Education, Al-Hussein Bin Talal University, Ma’an, Jordan. E-mail: habis.s.alzboon@ahu.edu.jo

Note: This research was funded by the Deanship of Scientific Research and Graduate Studies at Al-Hussein Bin Talal University

Received: August 31, 2020

Accepted: January 22, $2021 \quad$ Online Published: February 16, 2021

doi:10.5430/wje.v11n1p75

URL: https://doi.org/10.5430/wje.v11n1p75

\begin{abstract}
This research aims to identify science and mathematics teachers' attitudes towards integrating Information and Communication Technology (ICT) in their educational practice through applying the Unified Theory of Acceptance and Use of Technology (UTAUT). A questionnaire instrument was developed based on the constructs of the UTAUT (performance expectancy, effort expectancy, social influence and facilitating conditions) and attitudes scale. The study sample consisted of a group of mathematics and science teachers in governorate of Ma'an. The participants were randomly selected. Descriptive and regression analysis were used to analyze the data. The results showed the attitudes of science and mathematics teachers towards integrating information and communication technology in the educational process were high and positive. In addition, the results showed that science and mathematics teachers had positive and high perceptions of integrating information and communication technology in the educational process in all dimensions (performance expectancy, effort expectancy, social influence, and facilitating conditions). Furthermore, the unified theory of acceptance and use of technology was valid in explaining the attitudes of Science and Mathematics teachers toward the integration of ICT in the in their educational practice.
\end{abstract}

Keywords: UTAUT, ICT, science and mathematics teachers, Jordan

\section{Study Background}

The use of information and communication technology is playing an increasing role in escalating the efficiency of modern organizations including higher education institutions. The introduction of information and communication technology in higher education institutions have several benefits that include, but not limited to, improving students' performance (Aina, 2013; Gasaymeh, \& Aldalalah, 2013) enhancing students' attitudes toward learning (Gasaymeh, 2017; Gasaymeh, \& Qablan, 2013); Improving students' motivation (Hanafi, Said, Wahab, \& Samsuddin, 2017) increasing access and improve equity and quality of (Robinson, 2008).

However, the introduction of information and communication technology in higher education institutions, need planning and understating of the adoption of these technologies by students and faculty members. In this regard, there is a need to used validated tools and adoption models to examine the acceptance of information and communication technology, especially by teachers as they establish the success of the implementation of ICT in education. There are several change models and technology acceptance models that were developed to examine individuals' acceptance of the use of new innovations or technologies. One of the most promising models of this kind is the Unified Theory of Acceptance and Use of Technology (UTAUT). Based on many studies, UTAUT has been established to be an applicable model for explaining and predicting users' acceptance behavior regarding the use of new ICT in many situations.

Venkatesh et al, (2003) developed the UTAUT model that basically suggests that there four main variables would 
influence potential users' adoption of a new technology. These variables are performance expectancy, effort expectancy, social influence and facilitating conditions. In UTAUT, performance expectancy is defined as "the degree to which an individual believes that using the system will help him or her to attain gains in job performance" (Venkatesh et al., 2003, p. 447). Effort expectancy is defined as "the degree of ease associated with the use of the system" (Venkatesh et al., 2003, p. 450). Social influence is defined as "the degree to which an individual perceives that important others believe he or she should use the new system" (Venkatesh et al., 2003, p. 451). Facilitating conditions are defined as "the degree to which an individual believes that an organizational and technical infrastructure exists to support use of the system" (Venkatesh et al., 2003, p. 453).

There are several studies that employed UTAUT in the educational environments. Some of these studies examined students' acceptance of various technologies. For instance, Gasaymeh, (2018) conducted a study that aimed to examine the level of undergraduate students' use of ICT for personal and educational purposes. Two hundreds and fifty two students from a university in Jordan completed a questionnaire. The results showed that almost all the students owned smart-phones and greater part of them owned laptop computers. They had trouble-free access to ordinary types of technologies such as computers and the internet. They had fair competencies in the general use of these common technologies, and high competencies in using smartphones. They were users of ordinary digital tools and applications for non-educational purposes. Their ownership, access, competencies with, and use of ICT for personal purposes did not result in extensive use of ICT for educational purposes.

In another study, Attuquayefio and Addo (2014) used UTAUT model to analyze students' ICT adoption, the data were collected using a questionnaire from 345 students in the Social Studies and Business Administration Faculties in a university in Ghana. The results showed that only the effort expectancy factor significantly predicted behavioral intention to use ICT. In another study, Wong, Teo, and Russo (2013) employed UTAUT model to examine college of education students' acceptance of Interactive Whiteboard (IW) to be used in their teaching, where 159 student teachers completed a questionnaire that aimed to measure students' perceptions of performance expectancy, effort expectancy, social influence, facilitating condition and behavioral intention in relation to the use of (IW). The results showed that variables explained about $59.6 \%$ of the variance in students' behavioral intention in relation to the use of (IW) in their teaching.

There are other studies that focused on the instructor acceptance of the use of various technologies in education through employing UTAUT model and other technology acceptance models such as Concerns-Based Adoption Model (CBAM) and Technology Acceptance Model (TAM). For instance, Anderson, Schwager, and Kerns, (2006) conducted a study that aimed to utilize the UTAUT model to examine College of Business faculty members acceptance of the use Tablet PC in higher education. The results showed that "certain variables, namely performance expectancy and voluntariness, are the most salient drivers of acceptance when applied to business faculty in higher education"(p.429).

Gasaymeh (2017) conducted a study that looked at the concerns of faculty members regarding the acceptance of a Learning Management System (LMS) utilizing the Concerns-Based Adoption Model (CBAM). Forty-seven faculty members from a university in Jordan completed the Stages of Concern Questionnaire (SoCQ). The SoCQ was used to assess the strength of faculty members' concerns in seven areas: awareness, information, personal impact, management, consequences, collaboration and refocusing. The results showed that the respondents' concerns were greatest in the early stages of the introduction of the LMS. Faculty members had a general lack of awareness about LMS and did not have sufficient information about it. The faculty members had small attention in or engagement with the LMS; they wanted to know more about the consequence of LMS on them personally. Furthermore, faculty members had concerns about the management, time, and logistical aspects of the implementation of LMS.

Gasaymeh and Waswas, (2019) investigated students' acceptance of the official use of smartphones for their education using TAM. A descriptive qualitative approach was followed. Sixteen students participated in four interviews. The results showed that the participants expressed positive attitudes toward the use of smartphones for their learning. In line with the TAM model, the students reported the reasons for their positive attitudes toward the formal use of smartphones in learning. These reasons were strongly related to their perceptions of ease of use and the usefulness of smartphones for their daily life tasks and for informal learning.

The actual use and acceptance of ICT in the educational process were examined on different levels. For instance, on the university level, Al-Rsa'i (2012) conducted a study that aimed to examine the level of awareness that faculty members in colleges of science and engineering have concerning means of using technologies in a constructivist learning environment. The author used descriptive method in which a questionnaire instrument was used. The results showed that the faculty member know some technical skills while their awareness with the representation of information in diverse ways is high, but they were not aware with the methods of designing learning situations in an 
exploratory context through technology, nor are they familiar with employing this technology to develop higher-order thinking skills. Furthermore, Guillén-Gámez, \& Mayorga-Fernández, (2020) conducted a study that aimed to examine higher education teachers' attitudes towards (ICT). The participants were 867 university professors from Spain. The researchers used questionnaire to collect dat. The results show that these teachers have a medium total attitudinal level.

Furthermore, Unified Theory of Acceptance and Use of Technology (UTAUT) model has been also used in Arab world to examine teachers and students' attitudes toward the integration of different ICT in the educational process. For instance, In Kuwait, Almisad and Alsalim (2020) employed modified version of UTAUT to guide an investigation that aimed to examine Kuwaiti female university students' acceptance of the integration of smart-phones in their learning. The researchers collected data from 152 university students through the use of questionnaire. The results showed that that the independent variables explained about half of the variance in students' attitudes toward the use of smart-phones to support their learning. Only four independent variables namely; performance expectancy, effort expectancy, social influence, and facilitating conditions were individually significant in predicting students' attitudes toward the use of smartphones to support their learning.

In Palastine, Mahdi and Alhanawi, (2019) conducted a study that aimed to reveal the factors affecting the acceptance for the educational electronic portal by of faculty members at Al-Aqsa University and their use in the exchange of knowledge and university education according to the model (UTAUT). The researchers used the descriptive analytical method. To achieve the objectives of the study, the researchers designed the study tool consisting of five fields including (26) indicators. After applying the study tool to a sample of 30 faculty members who tried and used the electronic portal at Al-Aqsa University to exchange knowledge and university education, the study reached a set of results, the most important of which are: faculty members have an acceptable degree of portability in the exchange of knowledge and university education. The expected performance of faculty members also affects their behavioral intention to use the portal to exchange knowledge and university education according to the UTAUT model, in a positive way. The expected effort of the faculty members affects their behavioral intention to use the electronic portal to exchange knowledge and university education according to the UTAUT model positively. The motivational motivation of faculty members affects their behavioral intention to use the portal to exchange knowledge and university education according to the UTAUT model in a positive way. Facilitating conditions for faculty members affect their behavioral intention to use the electronic portal to exchange knowledge and university education according to the UTAUT model, positively. The social impact of faculty members also affects their behavioral intention to use the electronic portal to exchange knowledge and university education according to the UTAUT model in a positive way.

In Jordan, Shaqrah, (2015) examined the acceptance of group of Jordanian trainees' for e-learning technology based on UTAUT. The results showed that that the Jordanian trainees' behavior intention toward e- learning technologies is positive correlated with their performance expectancy; effort expectancy; web-based training infrastructure; trust; and culture. In Oman, Saleem, Al-Saqri, \& Ahmad, (2016) used UTAUT model to investigate the influence of constructs of the UTAUT (performance expectancy, effort expectancy, social influence and facilitating conditions) on faculty members' acceptance and their intention to use Moodle in their instruction. The researchers used qualitative research approach in which interviews were conducted with the faculty members. The results showed that the Moodle users believed that performance expectancy, effort expectancy, social influence, and facilitating conditions positively influence Moodle's adoption.

In Saudi Arabia, Lawrence, (2016) employed the UTAUT model to examine the reasons for accepting iPad tablets among group of college students who were studying English as a foreign language (EFL). For the purpose of the study 19 male students completed a questionnaire. The results showed students' perceptions of the educational benefits of the device and the availability of the needed perception infrastructure would support their acceptance of the iPad tablets, while social factors did not support their acceptance of the device. In another study that was conducted by Saudi coauthors, Almaiah, Alamri, and Al-Rahmi, (2019) used the UTAUT) model to investigate the effects of various factors on university students' acceptance of mobile learning applications on the university level. For the purpose of the study, six hundreds and ninety seven university students completed an online questionnaire. The results showed that "perceived information quality, perceived compatibility, perceived trust, perceived awareness, and availability of resources, self-efficacy, and perceived security are the main motivators of students' acceptance of mobile learning system" (p, 1).

The examined research studies show that UTAUT was popular model to examine the adoption of popular ICT in the educational institutions in Arab world. UTAUT model was used to guide the investigation of adoption of various ICT 
among students and instructors. Examples of these ICT include Interactive Whiteboard, educational electronic portals such as Moodle, and mobile learning applications. The current study employed UTAUT to examine Science and Mathematics teachers' acceptance of the use of ICT in general in their educational practice.

\section{Purpose of the Study}

The aims of the current study were twofold: to examine science and mathematics teachers' attitudes towards integrating information and communication technology in their educational practice and to examine the factors (performance expectancy, effort expectancy, social influence and facilitating conditions) that would shape science and mathematics teachers' attitudes towards integrating information and communication technology in their educational practice.

\section{Study Method and Design}

A descriptive quantitative research method was followed in the current study. A questionnaire was used to collect data. In this study, the questionnaire was used to examine participants' demographic characteristics, teachers' attitudes towards integrating information and communication technology, and their perceptions of some variables in relation to information and communication technology.

\subsection{Research Questions}

The current study aims to answer the following questions:

1. What are the science and mathematics teachers' attitudes towards integrating information and communication technology in their educational practice?

2. What is the relationship between science and mathematics teachers' attitudes towards integrating information and communication technology in their educational practice and their perceptions of the following variables in relation to information and communication technology:

- Performance expectancy.

- Effort expectancy.

- Social influence.

- Facilitating conditions.

3. Are there statistically significant differences at the level of $(\alpha=0.05)$ in the attitudes of science and mathematics teachers towards integrating information and communication technology in the educational process due to variables (gender, educational qualification, experience, age)?

\subsection{Participants}

Table 1. Descriptive Summary of Students Demographic Attributes

\begin{tabular}{llll}
\hline 'Variable & Category & Frequency & Per cent \\
\hline Gender & Male & 81 & $42 \%$ \\
& Female & 114 & $58 \%$ \\
Age & 22 to less than 30 & 58 & $30 \%$ \\
& 30 to less than 40 & 89 & $46 \%$ \\
Qualification & 40 and above & 48 & $24 \%$ \\
& Bachelor & 117 & $60 \%$ \\
\multirow{3}{*}{ Experience } & High Diploma & 57 & $29 \%$ \\
& Master or PhD & 21 & $11 \%$ \\
& Five years and less & 57 & $29 \%$ \\
Major & More than five and less than ten & 55 & $28 \%$ \\
& Ten years and more & 83 & $43 \%$ \\
& Mathematics & 91 & $46 \%$ \\
\end{tabular}


The study population consisted of science and mathematics teachers in government schools in the southern part of Hashemite Kingdom of Jordan, whose number was 612 in the first semester of academic year of 2019/2020. The study sample consisted of 195 teachers of mathematics and science in the pain of governmental secondary schools affiliated to the governorate of Ma'an and who were selected based on a simple random sampling method. Table 1 shows descriptive summary of students' demographic characteristics.

\subsection{Study Tool}

To achieve the goals of this study, a questionnaire was developed. The questionnaire consisted from three parts that aimed to gain information about participants' demographic variables, participants' attitudes toward the integration of ICT in their educational practice, and participants' perceptions of ICT integration in their educational practice in terms of performance expectancy, effort expectancy, social influence and facilitating conditions. Table 2 shows the questions in the questionnaire instrument.

Table 2. The Questions in the Questionnaire Instrument

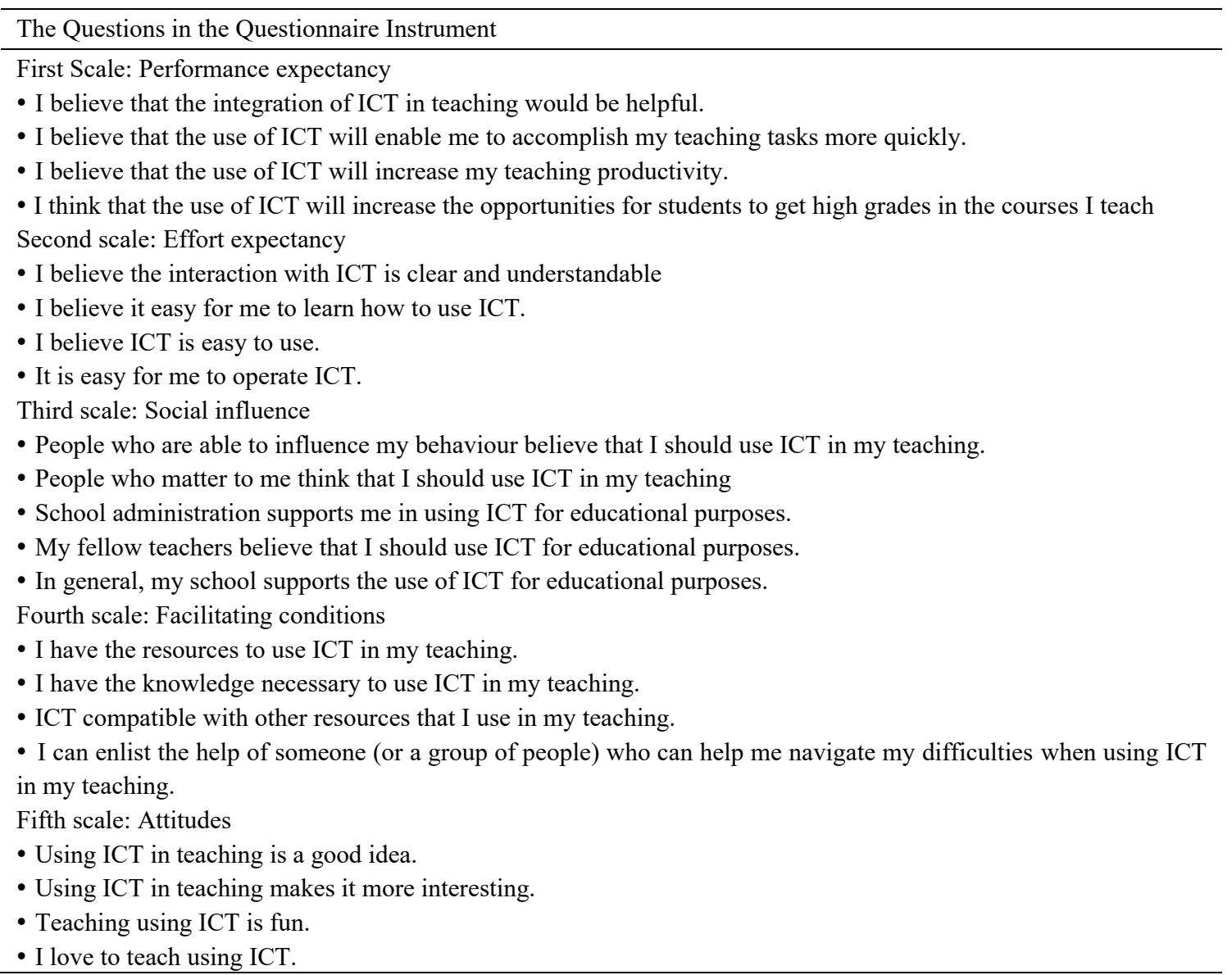

The validity and reliability of the questionnaire instrument were verified. The validity of the questionnaire instrument was verified through presenting the questionnaire to a group of faculty members in Jordanian universities who specialize in different fields that include: measurement and evaluation, educational technology and general curricula in the teaching of science and mathematics. The group of the faculty members was asked to express their views on the validity of the questionnaire's paragraphs and their comprehensiveness of the studied aspect, the belonging of each paragraph to its scope. In addition, they were asked to delete the inappropriate paragraphs or amend the paragraphs or transfer them from one field to another, or any other suggestions they deem appropriate . Their observations were taken as some of the paragraphs were modified, and no paragraph was added or deleted based on the percentage of the agreement between the arbitrators, as the percentage of agreement among them reached (\%85) and thus the questionnaire in its final form consisted of 21 paragraphs divided into five dimensions. Furthermore, a Pearson correlation coefficient was found between the degrees of each of the paragraphs of the questionnaire with the dimension to which it belongs and with the total score for it, through application to a 
survey sample of (30) examined from within the study community and outside the sample. The values of the correlation coefficients of the paragraphs with the dimension to which they belong Paragraph were between (0.41-0.92) and with the overall score $(0.42-0.86)$, all of which have statistical significance, so none of the paragraphs was deleted.

The reliability of the questionnaire instrument was verified through the use of Cronbach's Alpha for the participants' responses in the pilot study. The values of Cronbach's Alpha coefficients were high enough for the purpose of the study. Table 3 shows a summary of reliability analysis.

Table 3. Summary of Reliability Analysis

\begin{tabular}{lc}
\hline Scale & Cronbach's Alpha \\
\hline Performance expectancy & 0.82 \\
Effort expectancy & 0.77 \\
Attitude & 0.82 \\
Social influence & 0.66 \\
Facilitating conditions & 0.82 \\
Total & 0.87 \\
\hline
\end{tabular}

\subsection{Procedures}

The followed procedure in the current study involves conducting a comprehensive review of literature and the used technology acceptance model i.e., UTAUT. Based on the reviewed literature and the used technology acceptance model, a questionnaire instrument was developed. The validity and reliability of the questionnaire instrument were verified through the use of group of experts and statistical tests. The statistical tests were applied to the responses of group of participants outside the study sample in a pilot study procedure. Then, the final version of the questionnaire instrument was used to collect date from the participants regarding their perceptions of and attitudes towards integrating Information and Communication Technology in their educational practice. The questionnaires were handed to the participants with a help research assistant. The participants were verbally informed that the participation in the study was optional and their identity would be not be revealed under any circumstance. The participants completed the questionnaires and handed them back to the research assistant. Participants' responses were translated in to electronic form and exported into SPSS software for the next of data analysis.

\subsection{Data Analysis}

The first step in the data analysis was providing a qualitative descriptive for the participants' responses through determining three categories as in the following:

- Less than 2.33 is low.

- Between 2.34 and 3.67 is moderate.

- More than 3.68 is high.

After that frequency distributions for participants' demographic variables were founded in terms of participants' gender, age, qualification, experience, and major. In order to answer the first research question, the means ad standard deviations for participants' responses to the five scales of the questionnaire were calculated. These five scales were performance expectancy, effort expectancy, social influence, facilitating conditions, and attitudes. In order to answer the second research question, correlation and regression were conducted.

\section{Results and Discussion}

To answer the first question that was "What are the science and mathematics teachers' attitudes towards integrating information and communication technology in their educational practice?" Means, standard deviations, and qualitative description of the means' levels were provided. Table 4 shows means, standard deviations, and qualitative description of the means' levels for students' responses. 
Table 4. Means, Standard Deviations, and Qualitative Description of the Means' Levels for Students' Responses for the Five Scales that were Performance Expectancy, Effort Expectancy, Social Influence, Facilitating Conditions, and Attitudes

\begin{tabular}{lllll}
\hline & Scale & Mean & Standard deviation & Level \\
\hline 1 & Attitudes & 4.28 & 0.78 & High \\
2 & Performance expectancy & 4.18 & 0.80 & High \\
3 & Effort expectancy & 4.02 & 0.78 & High \\
4 & Social influence & 3.79 & 0.82 & High \\
5 & Facilitating conditions & 3.71 & 0.69 & High \\
\hline
\end{tabular}

It is clear from table 4 that the attitudes of science and mathematics teachers towards integrating information and communication technology in the educational process are positive with an average (3.98) and a standard deviation $(0.78$ )and that results was similar to science and mathematics teachers' perceptions of integrating information and communication technology in the educational process in all dimensions ( performance expectancy, effort expectancy, social influence, and facilitating conditions) as their means were high as 4.18,4.02,3.79, and 3.71 respectively. The participants responded most favorably to performance expectancy and least favorably to facilitating conditions.

The positive and high that the attitudes of science and mathematics teachers towards integrating information and communication technology in their educational process as well as their positive perceptions of integrating information and communication technology in the educational process in all dimensions ( performance expectancy, effort expectancy, social influence, and facilitating conditions ) might be attributed to the great attention provided to the science and mathematics teachers by Jordanian Ministry of Education. The ministry has provided training programs to help these teachers in developing their teaching methods in the classroom using modern educational strategies and technologies. The ministry provided these teachers with means of communication in order to share the latest educational technologies and teaching strategies, which strengthened the knowledge repository of teachers, by training them on the use of modern educational technologies during teaching and thus enhancing their attitudes towards integrating information and communication technology in the educational process. The findings regarding the positive and high that the attitudes of science and mathematics teachers towards integrating information and communication technology in their educational process as well as their positive perceptions of integrating information and communication technology in the educational process in all dimensions (performance expectancy, effort expectancy, social influence, and facilitating conditions) align with the findings of similar research studies (Shaqrah, 2015; Gasaymeh, 2018).

To answer the second question that was "What is the relationship between science and mathematics teachers' attitudes towards integrating information and communication technology in their educational practice and their perceptions of the following variables in relation to information and communication technology: performance expectancy, effort expectancy, social influence, and facilitating conditions." Correlations among participants' perception of performance expectancy, effort expectancy, social influence, and facilitating conditions of information and communication technology and attitudes toward the information and communication technology were calculated. Table 5 shows correlations values among participants' perception of performance expectancy, effort expectancy, social influence, and facilitating conditions of information and communication technology and attitudes toward the information and communication technology.

Table 5. Correlation Values among Participants' Perception of Performance Expectancy, Effort Expectancy, Social Influence, and Facilitating Conditions of Information and Communication Technology and Attitudes toward Integration of ICT in the in Their Educational Practice

\begin{tabular}{lllll}
\hline & Attitude & $\begin{array}{l}\text { Performance } \\
\text { expectancy }\end{array}$ & $\begin{array}{l}\text { Effort } \\
\text { expectancy }\end{array}$ & Social influence \\
\hline Attitudes & 1 & & & \\
Performance expectancy & $0.70^{* *}$ & & & \\
Effort expectancy & $0.48^{* *}$ & $0.39^{*}$ & $0.50^{* *}$ & \\
Social influence & $0.57^{* *}$ & $0.51^{* *}$ & $0.41^{*}$ & $* 0.39^{*}$ \\
Facilitating conditions & $0.40^{*}$ & $0.46^{* *}$ & \\
\hline
\end{tabular}

* Correlation is significant at the 0.05 level

** Correlation is significant at the 0.01 level. 
Based on table 5, significant relationships among the examined variables were verified. Teachers' attitudes toward the integration of ICT in the in their educational practice were directly related to their perception of performance expectancy, effort expectancy, social influence, and facilitating conditions in relation to information and communication technology. The results showed that the factor related to the participants' perceptions of the social influence has the strongest relationships with $(r=.57, p<0.01)$ with teachers' attitudes toward the integration of ICT in the in their educational practice. In addition, the results showed that the factor related to the participants' perceptions of the facilitating conditions has the weakest relationships $(r=0.40, p<0.05)$ with teachers' attitudes toward the integration of ICT in the in their educational practice.

Furthermore, to answer the second research question in terms of examining the potency of relationships between teachers' attitudes toward the integration of ICT in the in their educational practice and their perceptions of performance expectancy, effort expectancy, social influence, and facilitating conditions of information and communication technology (Table 6\&7).

Table 6. Stepwise Regression Model

\begin{tabular}{|c|c|c|c|c|c|c|}
\hline \multirow[b]{2}{*}{ Model } & \multirow[b]{2}{*}{$\mathrm{R}$} & \multirow[b]{2}{*}{ R Square } & \multirow[b]{2}{*}{$\begin{array}{l}\text { Adjusted R } \\
\text { Square }\end{array}$} & \multicolumn{3}{|c|}{ Change Statistics } \\
\hline & & & & $\begin{array}{l}\text { R Square } \\
\text { Change }\end{array}$ & $\begin{array}{l}\mathrm{F} \\
\text { Change }\end{array}$ & $\begin{array}{l}\text { Sig.F } \\
\text { Change }\end{array}$ \\
\hline 1. Performance Expectancy & .824 & 680 & .678 & 680 & 409.520 & .000 \\
\hline 2. Performance Expectancy +Social Influence & 920 & 847 & .845 & 167 & 209.095 & .000 \\
\hline $\begin{array}{l}\text { 3. Performance Expectancy +Social Influence } \\
+ \text { Effort Expectancy }\end{array}$ & .967 & .935 & .934 & .088 & 259.556 & .000 \\
\hline $\begin{array}{l}\text { 4. Performance Expectancy +Social Influence } \\
+ \text { Effort Expectancy + Facilitating Conditions }\end{array}$ & .985 & .970 & .969 & .035 & 222.579 & .000 \\
\hline
\end{tabular}

It appears from Table number 6 that the unified theory of acceptance and use of technology was valid in explaining the attitudes of Science and Mathematics teachers toward the integration of ICT in the in their educational practice, where the four factors: performance expectancy, effort expectancy, social influence, and facilitating conditions were successful in predicting the attitudes of Science and Mathematics teachers toward the integration of ICT in the in their educational practice. These factors have explained $97 \%$ of the attitudes of science and mathematics teachers towards integrating information and communication technology in the educational process as shown in this model, these values are statistically significant at the level of significance $(\alpha=0.05)$.

It was also shown that the greatest effect was from the expected performance that explains $68 \%$ of the variance in that variable of science and mathematics teachers' attitudes towards integrating information and communication technology in the educational process, followed by the social influence, which explained $16 \%$, followed by the effort expectancy which explained $9 \%$. Finally, the facilitating conditions variable, which explained $4 \%$ of science and mathematics teachers' attitudes towards integrating information and communication technology in the educational process.

This indicates the importance of the expected performance variable in explaining the attitudes of science and mathematics teachers towards integrating information and communication technology in their educational process, as it was the first variable that entered the regression equation, and this may be due to teachers' belief in the importance of integrating information and communication technology in teaching will be beneficial and enable them to accomplish teaching tasks more quickly, which increases their productivity and increase student achievement. The results showed that the facilitating terms variable explained the least percentage of the variance, and perhaps the reason for this is that the level of teachers' possession of the resources needed to use information and communication technology in my teaching was modest. The findings regarding the importance of the participants' perceptions of the variables: performance expectancy, effort expectancy, social influence, and facilitating conditions in relation to information and communication technology in explaining the attitudes of science and mathematics teachers towards integrating information and communication technology in their educational process align with the findings of similar research studies (Mahdi \& Alhanawi, 2019; Almaiah, Alamri, \& Al-Rahmi, 2019).

To identify the values of the regression and constant coefficients for the regression equation, the result of the regression analysis for the variables was found based on the last model. Table 7 shows the un-standardized and standardized coefficients for the regression equation. 
Table 7. Un-standardized and Standardized Coefficients as Result of Stepwise Regression Model

\begin{tabular}{lcccc}
\hline \multicolumn{1}{c}{ Variable } & $\mathrm{B}$ & $\mathrm{Beta}$ & $\mathrm{t}$ & $\mathrm{sig}$ \\
\hline Constant & 2.83 & & & \\
Performance Expectancy & 1.51 & 0.41 & 25.49 & 0.00 \\
Social Influence & 1.12 & 0.35 & 21.22 & 0.00 \\
Effort Expectancy & 1.11 & 0.28 & 17.66 & 0.00 \\
Facilitating Conditions & 1.09 & 0.22 & 14.91 & 0.00 \\
\hline
\end{tabular}

Table 7 shows that the values of Beta coefficients and $t$ coefficients indicate that the factors of the unified theory of acceptance and use of technology (performance expectancy, effort expectancy, social influence, and facilitating conditions) were significant in predicting the attitudes of Science and Mathematics teachers toward the integration of ICT in the in their educational practice, where it is noted that all the previous factors have had a positive impact on the attitudes of science and mathematics teachers towards the integration of information and communication technology in the educational process.

To answer the third question that was "Are there statistically significant differences at the level of $(\alpha=0.05)$ in the attitudes of science and mathematics teachers towards integrating information and communication technology in the educational process due to variables (gender, educational qualification, experience, age)?" The means and standard deviations for the participants' responses to the attitude scale was calculated according to the study variables (gender, educational qualification, experience, age) as shown in Table (8).

Table 8. Means and Standard Deviations for the Participants' Responses to the Attitude Scale was Calculated according to the Study Variables (Gender, Educational Qualification, Experience, Age)

\begin{tabular}{llll}
\hline Variable & levels & mean & Standard deviation \\
\hline Male & 4.24 & 0.83 \\
female & 4.08 & 0.76 \\
Bachelor & 4.09 & 0.82 \\
High Diploma & 4.28 & 0.80 \\
Master and Higher & 4.04 & 0.78 \\
Five years and les & 4.03 & 0.79 \\
More than five and less than ten & 4.10 & 0.84 \\
Ten years and more & 4.25 & 0.81 \\
22 to less than 30 & 4.00 & 0.85 \\
30 to less than 40 & 4.18 & 0.83 \\
40 and abov & 4.24 & 0.88 \\
Mathematics & 4.12 & 0.81 \\
Science & 4.16 & 0.80 \\
\hline
\end{tabular}

It is noted from the Table 8 that there are apparent differences between means for the participants' responses to the attitude scale due to the variables (gender, educational qualification, experience, age, specialization). Multiple responses to study sample responses. To verify the significance of the differences, multiple analyses of variance for the responses were conducted as shown in Table 9.

Table 9 shows that there are statistically significant differences at the level of significance $(\alpha=0.05)$ between the means of the individuals of the study sample for attitudes towards the integration of information and communication technology in the educational process due to the gender variable and in favor of males. There were no statistically significant differences at the level of significance $(\alpha=0.05)$ between the means of the individuals of the study sample for attitudes towards the integration of information and communication technology in the educational process due to (educational qualification, experience, age, major).

The reason for the differences in the attitudes of science and mathematics teachers towards integrating information and communication technology in the educational process and in favor of males may be due to the interest of male teachers towards integrating information and communication technology in the educational process more than female teachers, and this may be because they have received more training courses than female teachers. 
Table 9. The Results of the Analysis of Multiple Variances of the Means for the Participants' Responses to the Attitude Scale according to the Study Variables (Gender, Educational Qualification, Experience, Age)

\begin{tabular}{lccccc}
\hline Source & $\begin{array}{c}\text { Type III Sum of } \\
\text { Squares }\end{array}$ & df & Mean Square & F & Sig. \\
\hline Gender & 1385.091 & 2 & 692.546 & 7.407 & .001 \\
Qualification & 719.516 & 3 & 239.839 & 2.565 & .056 \\
Experience & 62.232 & 3 & 20.744 & .222 & .881 \\
Age & 197.892 & 2 & 98.946 & 1.058 & .349 \\
Major & 82.001 & 1 & 82.001 & .877 & .350 \\
Error & 17016.985 & 182 & 93.500 & & \\
Total & 1351075.000 & 194 & & & \\
Corrected Total & 19750.046 & 193 & & & \\
a. R Squared $=.138$ (Adjusted R Squared $=.086)$ & & & \\
\hline
\end{tabular}

\section{Conclusion and Recommendations}

The findings from the current study give the essential data as to how the ministry of education in Jordan can augment teachers' acceptance of ICT in order to maintain the usage of ICT in the educational process. These outcomes present significant suggestions for ICT acceptance and usage. The findings of current study add to the literature in relation to the acceptance of technologies by the academics. The findings suggest that there is a need to communicate the benefits of the ICT integration before asking the teachers to use them in their educational practice. Several recommendations for future studies can be provided based on the finding of the current study, more research can be conducted with different participants e.g., higher education teachers, school teachers from different majors, and school and university's students.

\section{References}

Aina, J. K. (2013). Integration of ICT into physics learning to improve students' academic achievement: Problems and solutions. Open Journal of Education, 1(4), 117-121. https://doi.org/10.12966/oje.07.01.2013

Almaiah, M. A., Alamri, M. M., \& Al-Rahmi, W. (2019). Applying the UTAUT Model to Explain the Students' Acceptance of Mobile Learning System in Higher Education. IEEE Access, 7, 174673-174686. https://doi.org/10.1109/ACCESS.2019.2957206

Almisad, B., \& Alsalim, M. (2020). Kuwaiti female university students' acceptance of the integration of smartphones in their learning: an investigation guided by a modified version of the unified theory of acceptance and use of technology (UTAUT). International Journal of Technology Enhanced Learning, 12(1), 1-19. https://doi.org/10.1504/IJTEL.2020.103812

Al-Rsa'i, M. S. (2012). The degree of knowledge that faculty members in colleges of science and engineering possess regarding ways and methods of using computers and modern technology in a constructivist learning environment. Journal of Turkish Science Education, 9(3), 87-96.

Anderson, J. E., Schwager, P. H., \& Kerns, R. L. (2006). The drivers for acceptance of tablet PCs by faculty in a college of business. Journal of Information Systems Education, 17(4), 429.

Attuquayefio, S., \& Addo, H. (2014). Using the UTAUT model to analyze students' ICT adoption. International Journal of Education and Development using ICT, 10(3), 75-86.

Gasaymeh, A. (2018). A study of undergraduate students' use of Information and Communication Technology (ICT) and the factors affecting their use: A developing country perspective. EURASIA Journal of Mathematics, Science and Technology Education, 14(5), 1731-1746. https://doi.org/10.29333/ejmste/85118

Gasaymeh, A. M. (2017). Faculty members' concerns about adopting a learning management system (LMS): A developing country perspective. EURASIA Journal of Mathematics, Science and Technology Education, 13(11), 7527-7537. https://doi.org/10.12973/ejmste/80014

Gasaymeh, A. M. M. (2017). University students use of WhatsApp and their perceptions regarding its possible integration into their education. Global Journal of Computer Science and Technology, 17(1).

Gasaymeh, A. M. M., \& Aldalalah, O. M. (2013). The Impact of Using SMS as Learning Support Tool on Students' 
Learning. International Education Studies, 6(10), 112-123. https://doi.org/10.5539/ies.v6n10p112

Gasaymeh, A. M. M., \& Qablan, B. M. (2013). SMS as Out-of-Class, Student-Instructor Interaction Tool: A Case Study of Jordanian Graduate Students' Perceptions and Usage. International Education Studies, 6(8), 147-160. https://doi.org/10.5539/ies.v6n8p147

Gasaymeh, A. M. M., \& Waswas, D. M. (2019). The use of TAM to investigate university students' acceptance of the formal use of smartphones for learning: a qualitative approach. International Journal of Technology Enhanced Learning, 11(2), 136-156. https://doi.org/10.1504/IJTEL.2019.098756

Guillén-Gámez, F. D., \& Mayorga-Fernández, M. J. (2020). Identification of variables that predict teachers' attitudes toward ICT in higher education for teaching and research: A study with regression. Sustainability, 12(4), 1312.

Hanafi, H. F., Said, C. S., Wahab, M. H., \& Samsuddin, K. (2017, August). Improving students' motivation in learning ict course with the use of a mobile augmented reality learning environment. IOP Conf. Ser. Mater. Sci. Eng, 226(1), 012114. https://doi.org/10.1088/1757-899X/226/1/012114

Lawrence, B. A. (2016). iPad Acceptance by English Learners in Saudi Arabia. English Language Teaching, 9(12), 34-46. https://doi.org/10.5539/elt.v9n12p34

Mahdi, H., \& Alhanawi, A. (2019). Factors affecting faculty's acceptance and using e-gate in teaching and knowledge exchange: a study utilizing UTAUT model at Al-Aqsa University. Educational Journal, 2(131).

Robinson, B. (2008). Using ICT and distance education to increase access, equity and quality of rural teachers' professional development. The International Review of Research in Open and Distributed Learning, 9(1). https://doi.org/10.19173/irrodl.v9i1.486

Saleem, N. E., Al-Saqri, M. N., \& Ahmad, S. E. (2016). Acceptance of Moodle as a teaching/learning tool by the faculty of the department of information studies at Sultan Qaboos University, Oman based on UTAUT. International Journal of Knowledge Content Development \& Technology, 6(2), 5-27. https://doi.org/10.5865/IJKCT.2016.6.2.005

Shaqrah, A. A. (2015). Explain the Behavior Intention to Use e-Learning Technologies: A Unified Theory of Acceptance and Use of Technology Perspective. International Journal of Web-Based Learning and Teaching Technologies (IJWLTT), 10(4), 19-32. https://doi.org/10.4018/IJWLTT.2015100102

Wong, K. T., Teo, T., \& Russo, S. (2013). Interactive whiteboard acceptance: Applicability of the UTAUT model to student teachers. The Asia-Pacific Education Researcher, 22(1), 1-10. https://doi.org/10.1007/s40299-012-0001-9

\section{Copyrights}

Copyright for this article is retained by the author(s), with first publication rights granted to the journal.

This is an open-access article distributed under the terms and conditions of the Creative Commons Attribution license (http://creativecommons.org/licenses/by/4.0/). 